\title{
Application of the Humid Thermal Index for Relating Bunted Kernel Incidence to Soilborne Tilletia indica Teliospores in an Arizona Durum Wheat Field
}

\author{
T. W. Allen and D. C. Jones, Texas AgriLife Research, 2301 Experiment Station Road, Bushland 79012-0010; \\ T. N. Boratynski, USDA APHIS PPQ, P.O. Box 37, Brawley, CA 92227-0037; R. E. Ykema, Arizona Department of \\ Agriculture, Phoenix 85009-2701; and C. M. Rush, Texas AgriLife Research, 2301 Experiment Station Road, Bush- \\ land 79012-0010
}

\begin{abstract}
Allen, T. W., Jones, D. C., Boratynski, T. N., Ykema, R. E., and Rush, C. M. 2009. Application of the humid thermal index for relating bunted kernel incidence to soilborne Tilletia indica teliospores in an Arizona durum wheat field. Plant Dis. 93:713-719.

A study was conducted to determine the relationship between soilborne Tilletia indica teliospore density and Karnal bunt incidence in an Arizona durum wheat field in 2005 and 2006. Soil samples were collected from 507 sample points according to a grid marked in a 7.7-ha field. Approximately $500 \mathrm{~g}$ of soil from the top $5 \mathrm{~cm}$ was collected from each sample point, and teliospores were recovered from $25 \mathrm{-g}$ aliquots by a modified size-selective sieving, sucrose centrifugation procedure. Twenty-five and 50 wheat heads were collected from a $1-\mathrm{m}^{2}$ area around each sample point in May 2005 and June 2006, respectively. Wheat head samples from each sample point were bulked, threshed, and examined for the presence of bunted kernels. Additionally, data for soilborne teliospores and percent bunted kernels from 70 sample points in 2005 and 2006 that corresponded to sample points from a 2004 bunted kernel survey conducted by the USDA and Arizona Department of Agriculture were analyzed. Soilborne teliospore numbers ranged from 6 to 1,000 per 25-g soil sample in the 2-year study. No bunted kernels were recovered in 2005; however, two sample points yielded bunted kernels in 2006. Weather data from three time periods in 2004, 2005, and 2006 were applied to the humid thermal index model and suggested that a conducive environment for disease development existed in 2005. Based on the data from this research, we concluded that even though high numbers of soilborne teliospores were present in the field, and although a conducive environment was present for disease to develop on only one occasion, a direct relationship between soilborne teliospores and disease incidence may not exist.
\end{abstract}

Karnal bunt (also referred to as partial bunt) of wheat, caused by Tilletia indica Mitra (三Neovossia indica (Mitra) Mundkur), has been a concern to wheat producers in the United States since it was first identified near Phoenix, AZ in 1996 (52). The fungal disease causes a partial conversion of wheat kernel tissue into sori filled with fetid teliospores $(10,49)$. Teliospores are dark-colored, thick-walled spores and serve as the primary source of inoculum for dissemination of the fungus and aid in long-term soil survival. Currently, over 40 nations have importation restrictions on wheat originating from areas where the disease occurs $(8,34,46)$. Recently, the European Union declared T. indica to be a quarantined pest in an effort to prevent the entry of the fungus into E.U. member

Corresponding author: C. M. Rush

E-mail: cm-rush@tamu.edu

Current address of T. W. Allen: Delta Research and Extension Center, Mississippi State University, Stoneville, MS

Accepted for publication 18 March 2009.

doi:10.1094/PDIS-93-7-0713

(C) 2009 The American Phytopathological Society states $(23-25,38)$ and deemed the fungus a high risk to establish in Europe with the potential to cause extreme economic consequences $(20,33,39)$. Due to the geopolitical nature of the disease, regulations were imposed on wheat originating in Arizona, California, and Texas following bunted kernel identifications in 1996, 1997, and 1997 , respectively $(8,18,34)$. As a result, these regulations caused financial hardship for farmers in the Rolling Plains of Texas, who experienced losses in excess of $\$ 25$ million during 2001 and 2002 due to a loss of the export market (34).

Previous research has documented the soil teliospore distribution from Texas $(1,46)$. Teliospores were reported to be widespread and occurred at high densities in some fields (greater than 1,000 teliospores per $25-\mathrm{g}$ soil sample). Teliospores were also reported from fields that had not previously tested positive for bunted kernels during APHIS surveys, and this raised questions regarding inoculum densitydisease incidence relationships for $T$. indica. Specific correlations between bunted kernel incidence and soilborne teliospores could not be made since the exact bunted kernel sampling location and total number of bunted kernels from each field were not known. Determining a relationship be- tween soilborne teliospores and bunted kernels from past information has proven difficult. The regulations by USDA-APHIS differ between states, and grain samples are not collected from georeferenced locations. More specifically, the regulations implemented in Texas by USDA-APHIS required verification of the presence or absence of bunted kernels from a $1.8-\mathrm{kg}$ grain subsample collected at harvest from wheat fields and not a bunted kernel quantity when verified (34). In Texas, a single bunted kernel rendered a field positive. Arizona regulations differ. Instead of collecting a subsample from grain harvested by the producer, USDA-APHIS (monitors Parker, AZ) and the Arizona Department of Agriculture (monitors Buckeye and Maricopa, AZ) harvest a random strip, usually at the easiest point of access, to collect a $1.8 \mathrm{-kg}$ sample. However, the entire sample was examined to acquire a total bunted kernel number for each field. Even though bunted kernel numbers are available for Arizona fields, the locations where bunted kernels occurred in individual fields were not georeferenced.

Harvested wheat containing greater than $3 \%$ bunted kernel incidence can reduce milling and baking quality, in part due to flour having a fishy odor $(3,26,48)$. However, bunted kernels, and the products derived from them, are not harmful if consumed by humans or animals $(9,34,41)$. This is a food quality issue rather than one of food safety. Additionally, the surveyed wheat fields within the United States have contained less than 3\% bunted kernels, with the majority of them containing $0.02 \%$ bunted kernels or less (34). A 2004 study in an Arizona durum wheat field found localized bunted kernel incidence that ranged from 0 to $11.1 \%$ with an average of $2.1 \%$ from the sampled locations (34). Even if a higher quantity of bunted kernels occurred, this could be rectified by blending with a disease-free grain sample.

Research concerning inoculum densitydisease incidence relationships for $T$. indica and Karnal bunt has not been previously published. Determining the association between inoculum density and disease incidence is fundamental in understanding plant disease epidemiology. Recently, inoculum density-disease incidence relationships for foliar disease systems (43) and soilborne disease systems $(17,27,28,51)$ 
were documented. A positive relationship, indicative of increasing inoculum density leading to increased disease incidence, was reported in both disease systems. Positive and negative relationships have been reported to occur between inoculum density and disease incidence in the bunt fungi. Goates and Peterson (16) reported a positive relationship between soilborne inoculum and incidence of dwarf bunt caused by Tilletia controversa. However, a stronger relationship was dependent upon conducive environmental conditions. Additionally, Pospisil et al. (32) studied the relation between common bunt teliospore inoculum (Tilletia caries (DC) Tul. and T. laevis Kühn) and disease incidence, but reported no correlation between spore density and disease incidence in field trials. Waldow and Jahn (47) reported numbers of seedborne $T$. caries teliospores were related to disease incidence in moderately and highly susceptible wheat varieties. However, all of the aforementioned work was conducted by infesting soil or wheat seed rather than looking at natural spore densities. Our study is the first of its kind to attempt to correlate naturally deposited soilborne teliospores of a bunt fungus to disease incidence. Determining the relationship between inoculum density and disease incidence for $T$. indica and Karnal bunt could help support the U.S. Karnal bunt pest risk assessment (PRA). In the past, predictive models such as Jhorar's humid thermal index (HTI) (21) have been relied upon to detect areas most suitable for Karnal bunt to occur $(6,29,44,45)$, rather than considering levels of infection in areas where the disease had already become established. However, the HTI model incorporates environmental factors that influence the production of sporidia, by accounting for temperature, humidity, and rainfall (21), and not Karnal bunt development. Thus, the model only predicts if the infective propagule will germinate from teliospores and not if disease development is likely. For this reason, we initiated a study to determine the relationship between soil teliospore density and bunted kernel (disease) incidence, and to determine if the HTI model could correctly predict conducive years based on the presence of bunted kernels.

\section{MATERIALS AND METHODS}

Study site. A 7.7-ha durum wheat field, located approximately $20 \mathrm{~km}$ west of Phoenix, AZ, that tested positive for bunted kernels in 2003 was chosen for a USDA-APHIS and Arizona Department of Agriculture bunted kernel survey in 2004. The field was planted with cv. Kronos, a Karnal bunt-susceptible variety, from 2003 to 2006. In 2003, this wheat field was identified as having 411 bunted kernels from a $1.8-\mathrm{kg}$ sample. In addition to wheat, corn was double cropped in the summer following the June wheat harvest each year.
Bunted kernel distribution, 2004. In May 2004, the USDA-APHIS and Arizona Department of Agriculture conducted a bunted kernel survey in this particular durum wheat field. For sampling, the field was partitioned into 8 rows, separated by approximately $31 \mathrm{~m}$, with rows starting and ending approximately $10 \mathrm{~m}$ from the west and east edges of the field, respectively. Fifty wheat heads were collected within eight 1.8-m-diameter sampling points, spaced every $15.2 \mathrm{~m}$, within each row ( $n=48$ points per row), for a total of 384 sample points. Wheat heads from each collection point were bulked, threshed, and examined for bunted kernels.

Soil and wheat head sampling, 2005 and 2006. In February 2005, the wheat field was separated into 13 rows, beginning approximately $10 \mathrm{~m}$ from the western edge of the field. Row spacings were a result of the land-formed levee system used in the field for flood irrigation purposes. The distance between major rows (defined as the distance between rows 1 to 2, 3 to 4,5 to 6,7 to 8,9 to 10 , and 11 to 12) was $19.5 \mathrm{~m}$, while the distance between minor rows (defined as the distance between rows 2 to 3,4 to 5,6 to 7,8 to 9 , 10 to 11 , and 12 to 13 ) was $11.5 \mathrm{~m}$. A total of 39 sample points were identified from within each row, running from south to north, and separated by approximately 7.6 $\mathrm{m}(n=507)$. At each sample point, three scoops of soil were collected with a hand trowel from the top $5 \mathrm{~cm}$, within a $1-\mathrm{m}^{2}$ area, representing approximately $500 \mathrm{~g}$ of soil. Sample points were marked with flags so wheat heads could be harvested from the same location at the end of the season. The perimeter and center of the wheat field were mapped using a Hewlett Packard Jornada Pocket PC (Hewlett Packard Inc., Palo Alto, CA) with Farm Works Mate software (Version 8.01; CTN Data Service Inc., Hamilton, IN). A field map was created using perimeter sampling points and interpolating the locations of interior points based on distance using ArcMap (Version 8; ESRI, Redlands, CA). In February 2006, the same points were resampled as above using a GPS device. For the purposes of comparing the 2004 bunted kernel data to teliospore collections from 2005 and 2006, seven rows (rows 1, 3, 5, $7,9,11$, and 13) from the latter design overlapped the 2004 design.

A portion of the wheat field was converted to a recreational area after sampling in February, preventing head collection from 78 sample points. On 30 May 2005, 25 wheat heads were collected from each remaining sample point $(n=429)$. Wheat heads were hand harvested from a $1-\mathrm{m}^{2}$ area directly above each flagged soil sample point. In May 2006, 50 wheat heads, instead of 25 , were collected from each sample point.

To determine if teliospore deposition occurred following the 2005-2006 wheat season, soil samples were collected following the 2006 growing season. Soil was collected from 17 randomly selected, previously sampled points by returning to the specific locations, using sample coordinates and a GPS unit. Soil samples were also collected from three additional sample points where bunted kernels were recovered from the 2006 growing season.

Each year, soil samples and wheat heads were transported to the Texas Agricultural Experiment Station Karnal Bunt Quarantine Lab in Bushland, TX and stored under ambient laboratory conditions (approximately $22^{\circ} \mathrm{C}$ ) prior to and during processing. All movement of soil and wheat heads from Arizona to the quarantine laboratory in Bushland was approved by USDAAPHIS and the Texas Department of Agriculture.

Soil preparation and teliospore extraction. Soil samples were air-dried in a Type IIA Biological fume hood for 3 to 5 days, and large clumps were broken with a rolling pin. Individual bags of soil, representing each sample point, were homogenized, and a $25-\mathrm{g}$ aliquot was placed into a 50-ml plastic screw-cap centrifuge tube. Teliospores were extracted, identified, and enumerated as described by Allen et al. (1).

Soil data analyses. Analyses of data were conducted on 70 points, corresponding to 7 rows with 10 sample points in each row, from the 2004 USDA bunted kernel survey that overlapped with our soil sampling and wheat head collections conducted in 2005 and 2006. The term "overlapping" describes the points in the survey grid within the field in the same measured location. Regression analyses were conducted to determine the relationships between 2004 bunted kernel collections and 2005 and 2006 soilborne teliospore data using PROC GLM in SAS 9.1 (SAS, Inc., Cary, NC). Regression analysis was also conducted on the 2005 and 2006 soilborne teliospore data.

Bunted kernel survey, 2005 and 2006. Individual wheat heads were threshed using a single head thresher (Precision Machine Company, Lincoln, NE) operated inside a Type IIA Biological fume hood to limit laboratory contamination. Grain was stored in paper bags, maintained under laboratory conditions until kernels could be examined for signs of the disease. In 2004, threshed grain was observed for bunted kernels by the Arizona Department of Agriculture using a treated seed inspection station (110V model TSIS, Hoffman Manufacturing, Albany, OR) with slight modifications. The inspection station uses a vibrating mechanism to move the seed down an inclined surface and underneath an illuminated (Sylvania DuluxS 13 watt bulb, Osram Sylvania, Danvers, MA), magnified area. Modifications to meet USDA specifications included removal of the original suction apparatus and the container used for specimen isolation and 
removal. Metal trays were replaced with plastic, to ease cleaning with bleach between seed lots positive for bunted kernels. Stainless steel hoppers replaced the original hoppers to decrease corrosion. The original magnifying lens was removed and replaced with $\mathrm{a} \times 3$ diopter lens (Model \#3750, Dana Lighting, West Bridgewater, MA). All kernels from each sampled location were observed for the presence of bunted kernels. Suspected kernels were separated and examined at a separate station using a $\times 10$ stereomicroscope for positive confirmation. When bunted kernels were detected, the inspection station was thoroughly cleaned with bleach to limit the possibility of contamination between seed lots.

The percentage of bunted kernels from each sampling point in 2004 was calculated based on the formula $\{[\#$ bunted kernels/(entire kernel sample weight from each point $)(18)] \times 100 \%$, where 18 is the number of durum wheat kernels per gram based on Arizona 1,000 kernel weights for cv. Kronos.

In 2005 and 2006, wheat heads were threshed, and grain was collected and stored until it could be transported to the USDA-APHIS facility in Seymour, TX for bunted kernel identification. In Seymour, kernels from each sample point $(n=429$ for 2005, $n=473$ for 2006) were examined for bunted kernels as outlined above, and the total number of bunted kernels from each sample was recorded.

Assessments of weather conditions. Assessments using the humid thermal index (HTI) model (21) were conducted to determine if Karnal bunt-conducive weather conditions existed during the 2004, 2005, and 2006 wheat growing seasons. Typically, durum wheat is planted in the Phoenix, AZ area during early December. The HTI model is based on specific weather variables collected during important wheat growth stages, generally considered to be boot through anthesis (Feekes 10.0 through 10.5 .1$)$. The HTI is calcu- lated by dividing the afternoon (termed evening in the original model description) relative humidity (ERH) recorded at 1430 hours (2:30 P.M.) by the average maximum temperature (TMX) for each day. A calculated HTI of 2.2 to 3.3 means that weather conditions are favorable for infection to occur. In the original HTI model, based on data from Punjab, India, the ERH and TMX were obtained by calculating the average of data from the 9th, 10th, and 11th standard meteorological weeks (SMW) following the planting date.

Weather data for December 2003 through May 2006 were downloaded from two weather data stations (http://ag. arizona.edu/AZMET/) located in Buckeye and Waddell, AZ, approximately 25.7 and $19.3 \mathrm{~km}$, respectively, from the research field. Both weather stations are located in irrigated agricultural settings and were assumed to have relative humidities similar to that of the irrigated wheat field.

To complete the assessments, data from three time periods were entered into the predictive model. This was primarily conducted to assess conducive environmental conditions across a broader time period. Firstly, weather data corresponding to the 9th through 11th SMWs following planting date were used. A second set of meteorological data was used for Maricopa County, AZ that corresponds to the average conducive growth stage period for Maricopa County (10 to 31 March) based on 10 years of observations (G. Peterson, personal communication). Additionally, a third set of meteorological data was collected and comparisons were made using growth stages calculated from growing degree days (GDD) data based on heat units $\left(30 / 7.2^{\circ} \mathrm{C}\right)$ provided by the University of Arizona, AZMET weather data service. Developmental stages were determined by the number of GDD (24) for durum wheat and tended to be approximately 971 for the beginning of heading (Feekes 10.0) and carried through hard dough (Feekes 11.2), which tended to oc- cur following approximately 1,470 heat units.

\section{RESULTS}

Bunted kernel distribution, 2004. Bunted kernel incidence from 70 sample points ranged from 1 to 247 with an average of 47 (Table 1). Average bunted kernel incidence from each sampling point ranged from 0.1 to $11.1 \%$ with an average of $2.05 \%$ based on the kernel sample weight from each point. A contour map of the bunted kernel incidence was previously presented by Rush et al. (34). In general, a greater number of bunted kernels was recovered from the western edge of the field (Table 1) than from the remainder of the field. A total of 3,267 bunted kernels were collected and $31.2 \%$ of the bunted kernels occurred in the first row on the western edge of the field (presented as row 1). Row 3 , the second row from the west, had the second highest number of bunted kernels but only represented $17.6 \%$ of all bunted kernels collected.

Soil data analyses. Teliospore numbers are presented as the number recovered from 25 -g soil aliquots. A low but significant relationship between soilborne teliospore numbers recovered from 2005 and 2006 was observed $\left(y=0.00003 x^{2}+\right.$ $\left.0.1922 x+78.315 ; R^{2}=0.384 ; P<0.0001\right)$ (data not presented).

Soilborne teliospore numbers were highly variable across the field in 2005 and 2006. The number of extracted teliospores ranged from 6 to 1,000 (Table 2). Seventy overlapping points were sampled in the 2 years, but in 2006 two points were lost due to the conversion of a portion of the field into a recreational area. Among the remaining 68 points, there were differences in the number of teliospores recovered between 2005 and 2006. A total of 19 points, or $29 \%$ of the points sampled, had an increase in the number of teliospores recovered in 2006 over 2005 (Table 2). Percent teliospore increases ranged from 9 to $63 \%$, with an average of $38 \%$. The re-

Table 1. Number of bunted kernels recovered from 50 wheat heads collected from each of 70 sample locations (points), collected in 2004, corresponding to soil sampling points in 2005 and 2006

\begin{tabular}{|c|c|c|c|c|c|c|c|}
\hline \multirow{2}{*}{$\begin{array}{l}\text { Sample point } \\
\text { (south to north) }^{\text {b }}\end{array}$} & \multicolumn{7}{|c|}{ Rows (west to east) $^{\mathbf{a}}$} \\
\hline & 1 & 3 & 5 & 7 & 9 & 11 & 13 \\
\hline 33 & $144^{\mathrm{c}}$ & 52 & 21 & 176 & 11 & 30 & 19 \\
\hline 27 & 122 & 46 & 23 & 119 & 2 & 31 & 34 \\
\hline 22 & 214 & 3 & 15 & 15 & 23 & 8 & 16 \\
\hline 21 & 247 & 14 & 23 & 6 & 23 & 32 & 26 \\
\hline 16 & 81 & 87 & 40 & 115 & 22 & 26 & 52 \\
\hline 15 & 67 & 69 & 46 & 13 & 11 & 13 & 52 \\
\hline 10 & 42 & 82 & 1 & 2 & 12 & 33 & 27 \\
\hline 9 & 16 & 215 & 1 & 1 & 32 & 52 & 16 \\
\hline 4 & 24 & 1 & 64 & 8 & 33 & 56 & 9 \\
\hline 3 & 64 & 7 & 98 & 87 & 56 & 26 & 13 \\
\hline Total & 1,021 & 576 & 332 & 542 & 225 & 307 & 264 \\
\hline
\end{tabular}

\footnotetext{
${ }^{\text {a }}$ Rows were separated by approximately $38.1 \mathrm{~m}$ on a west-to-east grid.

b Sample points from the 2004 bunted kernel sampling correspond to soil sample points collected in 2005 and 2006. Sample points differ in their distance from one another, but in general, points were $7.6 \mathrm{~m}$ apart for those with sequential numbers. Points with the lowest numbers are at the southern edge of the field.

${ }^{\mathrm{c}}$ Number of bunted kernels recovered from 50 wheat heads. Wheat heads were recovered from within a 1.8-m-diameter sampling point.
} 
maining 49 sample points had a decrease in the number of teliospores present in 2006 compared to 2005 . The percent decreases ranged between 2 and $95 \%$ with an average decrease of $44 \%$. A total of 16,497 teliospores were recovered in 2005, compared to 10,703 in 2006 , a $35 \%$ decrease between the 2 years. Teliospores were recovered from 20 locations following the harvest in 2006 (data not presented). The number of recovered teliospores increased at five of the locations, increasing between 5 and 71 teliospores over the 2006 extracted numbers, or 14 to $61 \%$ (data not presented). Teliospores decreased at the other 15 locations, decreasing between 1 and 473 teliospores, or 5 to $99 \%$.

Bunted kernel survey, 2005 and 2006. In 2005, bunted kernels were not observed from approximately $23 \mathrm{~kg}$ of grain harvested from 429 locations (Table 3). However, in 2006, two adjacent sample points (immediately north and south of one another and separated by approximately 7.6 m) contained 6 and 18 bunted kernels. These bunted kernels represented 0.32 and $0.34 \%$ of the wheat kernel samples harvested at these points based on total sample weight. Overall, $1.27 \mathrm{~g}$ of bunted kernels were collected from the two sample points, representing $0.002 \%$ of the grain sample from the 68 points. One additional sample point, located within a USDA fungicide research plot (and inclusive of our sample location), contained six bunted kernels; however, bunted kernels were not found in our harvested samples from the immediate area. At the three locations where bunted kernels were recovered in 2006, recovered numbers of soilborne teliospores decreased at two of the locations and increased at a single location (Table 3).

Assessments of weather conditions. Over the three time periods assessed, the HTI ranged from -0.29 (not conducive) to 2.75 (highly conducive) (Table 4). There were minor differences in the values calcu- lated with the data from the two weather stations. In 2004 and 2005, the 9th through 11th SMW yielded greater values, suggesting there was a more conducive environment for infection during this time period. However, these 3 weeks typically occur at growth stages not generally believed to be conducive for infection since the head has not emerged from the boot. In the 2004 growing season, wheat was planted on 22 December 2003, later than normal, due to excessive December rains. This meant that the conducive period was later than in the following two years and occurred between 23 February 2004 (9th week) and 14 March (11th week). Only one year, 2005, was predicted to have conducive weather conditions for disease development (HTI = 2.71 to 2.75 , depending on weather station) (Table 4). However, bunted kernels were reported in two of the three years (2004 and 2006).

\section{DISCUSSION}

In our 2006 sampling, only 24 bunted kernels were recovered. This represents $0.002 \%$ of the entire sample, substantially lower than an amount that would reduce flour quality. This suggests that even with continuous wheat production and high soilborne teliospore numbers at some locations, either environmental conditions during susceptible wheat developmental stages were not conducive for infection, or another, undetermined factor is necessary to induce infection. Even though teliospores are an important structure for survival and dissemination of the fungus, sporidia may ultimately play a more important role $(10,14,15,40)$. Bunted kernels were first detected in our field in 2003. Historically, this Arizona field yielded the greatest number of bunted kernels in 2003 and 2004 (411 and 478, respectively) of all the fields surveyed in the United States. These are the highest bunted kernel numbers reported from a U.S. production wheat field. To put this into perspective, the next highest numbers of bunted kernels recovered from Arizona durum wheat fields were 24 and 187 in 2003 and 2004, respectively.

Based on 3 years of HTI model weather data comparisons, the only conducive period for Karnal bunt was during the 9th through 11th standard meteorological weeks in 2005 . However, the wheat growth stages related to these dates have not pre-

Table 3. Bunted kernel incidence and corresponding teliospore numbers from three sampling points in an Arizona durum wheat field from February 2005 and 2006, and postharvest 2006 teliospore numbers $^{\mathrm{a}}$

\begin{tabular}{|c|c|c|c|c|c|}
\hline & \multicolumn{2}{|c|}{$2005^{\mathrm{b}}(n=429)$} & \multicolumn{2}{|c|}{$2006(n=473)$} & \multirow{2}{*}{$\begin{array}{c}2006 \text { postharv. } \\
\text { Teliospores }\end{array}$} \\
\hline & Teliospores $^{\mathrm{d}}$ & Bunted kernels & Teliospores & Bunted kernels & \\
\hline Row 6: pt 30 & 130 & 0 & 105 & 6 & 95 \\
\hline Row 6: pt 31 & 149 & 0 & 107 & 18 & 82 \\
\hline Row 11:pt $4^{\mathrm{e}}$ & 30 & 0 & 37 & 6 & 72 \\
\hline
\end{tabular}

a Bunted kernels were only recovered from three locations in 2006.

b Twenty-five wheat heads were collected from each sample point in 2005, and 50 wheat heads were collected from each point in 2006.

c Soil samples were collected from sample locations corresponding to bunted kernel isolations to determine possible teliospore deposition following disease incidence.

$\mathrm{d}$ Total teliospore numbers were extracted from $25-\mathrm{g}$ soil aliquots by a size-selective sieving, sucrose centrifugation procedure (1).

e Bunted kernels were not recovered from this point in our survey. However, the USDA had a fungicide trial at this location and recovered bunted kernels.

Table 2. Soilborne teliospore counts from 70 sample points, collected in 2005 and 2006, corresponding to wheat head sampling points from a 2004 joint study between the USDA-APHIS and Arizona Department of Agriculture to determine the bunted kernel distribution in an Arizona durum wheat field

\begin{tabular}{|c|c|c|c|c|c|c|c|c|c|c|c|c|c|c|}
\hline \multirow{3}{*}{$\begin{array}{l}\text { Sample } \\
\text { point (south } \\
\text { to north) }\end{array}$} & \multicolumn{14}{|c|}{ Rows (west to east) ${ }^{\mathbf{a}}$} \\
\hline & \multicolumn{2}{|c|}{1} & \multicolumn{2}{|c|}{3} & \multicolumn{2}{|c|}{5} & \multicolumn{2}{|c|}{7} & \multicolumn{2}{|c|}{9} & \multicolumn{2}{|c|}{11} & \multicolumn{2}{|c|}{13} \\
\hline & 2005 & 2006 & 2005 & 2006 & 2005 & 2006 & 2005 & 2006 & 2005 & 2006 & 2005 & 2006 & 2005 & 2006 \\
\hline 33 & $145^{\mathrm{c}}$ & 125 & 505 & 564 & 275 & 160 & 314 & 229 & 61 & 335 & 42 & 66 & 61 & - \\
\hline 27 & 270 & 229 & 1,000 & 682 & 198 & 138 & 397 & 280 & 67 & 172 & 74 & 58 & 85 & - \\
\hline 22 & 211 & 145 & 599 & 532 & 390 & 191 & 395 & 124 & 158 & 76 & 21 & 32 & 144 & 30 \\
\hline 21 & 314 & 225 & 585 & 542 & 394 & 121 & 301 & 122 & 136 & 103 & 38 & 10 & 175 & 19 \\
\hline 16 & 231 & 175 & 318 & 131 & 173 & 148 & 451 & 90 & 121 & 133 & 40 & 45 & 305 & 16 \\
\hline 15 & 502 & 187 & 582 & 115 & 163 & 148 & 654 & 101 & 56 & 79 & 54 & 52 & 128 & 42 \\
\hline 10 & 294 & 289 & 313 & 81 & 331 & 260 & 197 & 155 & 81 & 123 & 52 & 60 & 52 & 20 \\
\hline 9 & 381 & 473 & 425 & 123 & 461 & 197 & 167 & 148 & 289 & 93 & 44 & 32 & 48 & 23 \\
\hline 4 & 235 & 135 & 589 & 135 & 138 & 213 & 151 & 119 & 53 & 118 & 30 & 37 & 8 & 16 \\
\hline 3 & 176 & 475 & 477 & 97 & 134 & 128 & 150 & 96 & 33 & 138 & 49 & 149 & 6 & 8 \\
\hline Total & 2,759 & 2,448 & 5,393 & 3,002 & 2,657 & 1,704 & 3,177 & 1,464 & 1,055 & 1,370 & 444 & 541 & 1,012 & 174 \\
\hline
\end{tabular}

\footnotetext{
${ }^{a}$ Rows overlapped the 2004 wheat head sampling rows and were separated by approximately $22 \mathrm{~m}$ on a west-to-east grid.

${ }^{\mathrm{b}}$ Sample points differ in their distance from one another, but in general points were $7.6 \mathrm{~m}$ apart for those with sequential numbers. Points with the lowest numbers are at the southern edge of the field.

c Teliospores were extracted from 25 -g soil aliquots from each sample location using a size-selective sieving, sucrose centrifugation procedure (1).
} 
viously been associated with a susceptible growth stage, and bunted kernels were not recovered in 2005. Two particular variables, irrigation and duration of the conducive wheat growth stages, might have altered the predictive ability of the HTI model. Arizona wheat development requires irrigation, and seven irrigation events are typically scheduled throughout the growing season (31), with three occurring during those growth stages considered to be most conducive for Karnal bunt infection: preboot, heading to flowering, and milk (19). Similarly, the irrigation recommendations for wheat grown in northwest India, where Karnal bunt is so prevalent, suggest six irrigation events during the growing season (23) with one irrigation coinciding with flowering. Establishing whether or not Karnal bunt development is influenced by irrigation timing would be difficult to determine; however, irrigation increases localized humidity and reduces temperatures. Generally speaking, low temperatures and high humidity favor Karnal bunt development and would result in HTI values within the conducive range. The HTI model was previously used to predict whether or not wheat growing regions in the United States and Mexico were at risk to Karnal bunt $(8,9,42)$. It was also applied to weather data from Australia and South Africa $(44,45)$, and used in predicting whether or not the United Kingdom and European Union were at risk of Karnal bunt development (36). Other models $(5,42,50)$, including the one created by Smiley (42) that relied on temperature and rainfall events leading to high humidity levels during wheat anthesis, have been applied to the world's wheat growing regions. However, Smiley's model failed to identify Sonora and Sinaloa in coastal Mexico, where Karnal bunt has been established for decades $(12,23)$. In the past, the HTI model has also failed to predict Kar- nal bunt in locations that have already reported the disease, including parts of Arizona (44). This suggests that a new, more reliable model may be needed based on the specific, regional weather conditions in Arizona and California where irrigation might factor into Karnal bunt incidence. One such model, recently developed by Workneh et al. (50), utilized Doppler radar technology to successfully predict Karnal bunt-positive and -negative fields in two Karnal bunt-positive Texas regions. In the current study, the period of time between conducive growth stages (16 to 20 days in 2004 versus 32 to 37 days in 2005 and 2006), considered to be from boot through anthesis $(8,10,49)$, could have altered the model's predictive ability. However, a longer period of time between conducive growth stages, as occurred in 2005 and 2006, should have meant there was a greater opportunity for infection to occur. Essentially, a difference in the average temperature between 2004, 2005, and $2006\left(30.1^{\circ} \mathrm{C}\right.$ in 2004 versus 24.5 and $22.2^{\circ} \mathrm{C}$ for 2005 and 2006 , respectively) was likely the reason for the extended duration during the 2005 and 2006 GDD growth stage calculations. Within this particular time period, a conducive environment for Karnal bunt development did not occur. This suggests that either specific microclimates occur within Karnal buntpositive fields or irrigation impacts disease development. However, it should be noted that Karnal bunt incidence is more strongly correlated with rainfall than with irrigation $(8,21,23,42,50)$. Even though a conducive environment occurred in 2005 during the 9th through 11th SMW, these weeks tend to occur from 14 February to 14 March, depending on planting date, and correspond to one to two nodes through last leaf visible (31). In general, these wheat growth stages have not been reported to be susceptible for $T$. indica infection and the resulting development of Karnal bunt.

Karnal bunt is a disease of minor yield and quality consequence $(4,7,8,23-25,34)$. However, severe trade restrictions have been placed on those countries that attempt to export wheat from infected growing regions. Within the past several years, the E.U. has conducted $T$. indica teliospore survivability studies in areas where the pathogen and resulting disease have not been reported $(20,39)$. In fact, three PRAs $(35,37,38)$ have originated from the E.U., with the most recent released in 2006 as part of the European Commission's Fifth Framework Project. Essentially, the body of work and concluding remarks suggest that a single teliospore or bunted kernel, released into the soil profile, possibly during transport of bunted kernels or teliospore infested kernels, could incite disease. Over time, with more disease foci occurring, the soil could become increasingly infested and result in a greater Karnal bunt threat. However, the data generated in the current project, and by Allen et al. (1), suggest that even if soils are infested with high numbers of widely distributed teliospores, and unless highly specific environmental conditions conducive for disease development (based on finding bunted kernels, not model predictions) occur, that bunted kernel incidence could be extremely low and the impact on yield and quality negligible. Even though Jones $(22,24,25)$ stated that $T$. indica teliospores were likely internationally distributed in germplasm and/or commercial seed lots, and then field sown, over a period of many years without the disease ever occurring, one trace forward did result. Two seed lines and one cultivar, originating from the International Maize and Wheat Improvement Center (CIMMYT), reportedly induced field-level disease (11). Bunted kernels were recovered following the 1989

Table 4. Humid thermal index (HTI) calculated for each year, 2004 to 2006, for a durum wheat field west of Phoenix, AZ, with two geographically different weather stations used to collect data

\begin{tabular}{|c|c|c|c|c|c|}
\hline \multirow[b]{2}{*}{ Year } & \multirow[b]{2}{*}{ Date planted } & \multirow[b]{2}{*}{ Weather station } & \multicolumn{3}{|c|}{ HTI $^{\mathbf{a}}$} \\
\hline & & & 9th through 11th SMW & March 10 through $31^{c}$ & GDD $^{d}$ \\
\hline \multirow[t]{2}{*}{2004} & $12 / 22 / 03$ & Buckeye & 1.58 (23 Feb. - 14 Mar.) & 0.11 & 0.31 (14 Mar. - 3 April) \\
\hline & & Waddell $\mathrm{f}^{\mathrm{f}}$ & 1.70 & 0.02 & 0.16 (6 Mar. - 22 Mar.) \\
\hline \multirow[t]{2}{*}{2005} & $12 / 13 / 04$ & Buckeye & $2.71 *(14 \text { Feb. }-6 \text { Mar. })^{\mathrm{g}}$ & 0.94 & $0.25-0.91^{\mathrm{h}}(11$ Mar. -12 April $)$ \\
\hline & & Waddell & $2.75^{*}$ & -0.14 & $0.19-0.93(9$ Mar. -12 April $)$ \\
\hline \multirow[t]{2}{*}{2006} & $12 / 15 / 05$ & Buckeye & 0.97 (16 Feb. - 8 Mar.) & 1.47 & $0.52-1.52$ (6 Mar. - 11 April) \\
\hline & & Waddell & 0.75 & 1.44 & $-0.29-1.49$ (2 Mar. -8 April $)$ \\
\hline
\end{tabular}

a HTI is based on the HTI calculations carried out by using the model proposed by Jhorar et al. (21). Dates for each period are included in parentheses following the HTI value.

b Jhorar et al. (21) found that meteorological data collected from the 9th through 11th standard meteorological weeks (SMW) in India, corresponding to weeks after planting, was the most conducive period for infection by Tilletia indica to occur.

${ }^{c}$ Based on 10 years of observations from Maricopa County wheat growth stages that correspond to boot through anthesis (Feekes 10.0 through 10.5.1).

${ }^{\mathrm{d}}$ Growing degree days (GDD) were calculated based on data collected throughout Arizona for durum wheat varieties (31). Dates for each period are included in parentheses following the HTI value.

e The Buckeye weather station is located approximately $25.7 \mathrm{~km}$ southwest of the research site

${ }^{\mathrm{f}}$ The Waddell weather station is located approximately $19.3 \mathrm{~km}$ northwest of the research site.

${ }^{g}$ An asterisk denotes a conducive environment for the development of Karnal bunt based on the HTI model developed by Jhorar et al. (21), where an HTI between 2.2 and 3.3 is considered to be conducive.

${ }^{\mathrm{h}}$ A range of HTI values is included in the GDD column as calculations were conducted on at least 3 sets of 21-day periods within the range of data gathered across the corresponding days due to an extended period of time between boot and anthesis. 
season. However, this was a limited outbreak and appears to have been eradicated since no further reports have been published. Additionally, it is possible that teliospores are not as important as is the durability and length of time that sporidia can survive prior to infecting wheat $(10,14,15)$. The possible dissemination of seedborne pathogens, both in and on transported seed, has been mentioned in the case of Karnal bunt since the 1980s (22). Based on our data, and that from other research projects $(1,2,14,46,50)$, it seems clear that even in situations where high levels of teliospores and infective plant growth stages are present, highly specific environmental conditions are required for Karnal bunt to develop $(4,23,24)$. Moreover, while a direct relationship could not be determined between the density of soilborne teliospores and bunted kernel incidence, this project has produced further evidence that the HTI model likely overestimates the possibility of Karnal bunt becoming established in new areas. Several researchers $(13,30,38)$ have made the assumption that there are a requisite threshold number of teliospores required for disease to develop. Therefore, our project is not the only one that has failed to relate soilborne teliospore levels to disease incidence. Numerous studies, most of which have gone unpublished, from the United States (G. Peterson, personal communication) and abroad (40) have reported similar results. The data from this project should help support development of an accurate PRA for Karnal bunt in the United States. It also demonstrates that further research on the relationship between number of soilborne teliospores and bunted kernel incidence, and the ultra-specific environmental conditions required for disease development, is necessary.

\section{ACKNOWLEDGMENTS}

This research was conducted under a specific cooperative agreement between the Texas Agriculture Experiment Station and USDA-ARS under project number 5430-21000-005-00D. We are grateful to C. Childers and F. Workneh for field assistance, and B. Annen, J. Arthur, D. Harvey, and H. W. Maples for technical assistance. We would also like to thank C. W. Randall and the rest of the staff working with the Karnal bunt project in Seymour/Olney, TX for assistance recovering bunted kernels. M. Ottman, Extension Agronomist for the University of Arizona, was also an invaluable source of specific Arizona cropping systems information throughout the development of this manuscript.

\section{LITERATURE CITED}

1. Allen, T. W., Maples, H. W., Workneh, F., Stein, J. M., and Rush, C. M. 2008. Distribution and recovery of Tilletia indica teliospores from regulated wheat fields in Texas. Plant Dis. 92:344-350.

2. Allen, T. W., Workneh, F., Steddom, K. C., Peterson, G. L., and Rush, C. M. 2008. The influence of tillage on dispersal of Tilletia indica teliospores from a concentrated point source. Plant Dis. 92:351-356.

3. Aujla, S. S., Grewal, A. S., Gill, K. S., and Sharma, I. 1980. Effect of Karnal bunt on chappati making properties of wheat grains.
Crop Improve. 7:147-149.

4. Babadoost, M. 2000. Comments on the zero tolerance quarantine of Karnal bunt of wheat. Plant Dis. 84:711-712.

5. Baker, R. H. A., Sansford, C. E., Gioli, B., Miglietta, F., Porter, J. R., and Ewert, F. 2005. Combining a disease model with a crop phenology model to assess and map pest risk: Karnal bunt disease (Tilletia indica) of wheat in Europe. Pages 89-94 in: Plant Protection and Plant Health in Europe: Introduction and Spread of Invasive Species. Proc. 81st Br. Crop Prot. Counc. Sympos. D. V. Alford and G. F. Backhaus, eds. Berlin, Germany.

6. Baker, R. H. A., Sansford, C. E., Jarvis, C. H., Cannon, R. J. C., MacLeod, A., and Walters, K. F. A. 2000. The role of somatic mapping in predicting the potential geographical distribution of non-indigenous pests under current and future climates. Agric. Ecosyst. Environ. 82:57-71.

7. Beattie, R. R., and Biggerstaff, D. R. 1999. Karnal bunt, a wimp of a disease-but an irresistible political opportunity. Choices 14:4-8.

8. Bonde, M. R., Peterson, G. L., Schaad, N. W., and Smilanick, J. L. 1997. Karnal bunt of wheat. Plant Dis. 81:1370-1377.

9. Bonde, M. R., and Smilanick, J. L. 1998. Life cycle and environmental requirements of Tilletia indica. Pages 137-148 in: Proc. Bunts and Smuts of Wheat: An International Symposium, Raleigh, NC, USA.

10. Carris, L. M., Castlebury, L. A., and Goates, B. J. 2006. Nonsystemic bunt fungi - Tilletia indica and T. horrida: A review of history, systematics, and biology. Annu. Rev. Phytopathol. 44:113-133.

11. Da Luz, W. C., Mendes, M. A. S., Ferreira, M. A. S. V., and Urben, A. F. 1993. Tilletia indica on wheat in the south of the state of Rio Grande do Sul, Brazil and measures for eradication. Fitopatol. Bras. 18:S329.

12. Dobesberger, E., Jiménez, N. A. E., and Sequeira, R. A. 2001. An epidemiological approach to assessing the risk of establishment of Karnal bunt, Tilletia indica Mitra, in North America. North American Plant Protection Organization (NAPPO) Pest Risk Assessment Panel Report, October 2001.

13. Garrett, K. A., and Bowden, R. L. 2002. An allee effect reduces the invasive potential of Tilletia indica. Phytopathology 92:1152-1159.

14. Goates, B. 2005. Durability of secondary sporidia of floret infecting Tilletia species: Implications for epidemiology. (Abstr.) Phytopathology 95:961.

15. Goates, B. J. 2006. Durability of secondary sporidia of floret infecting Tilletia species under laboratory and field condictions: Implications for epidemiology. Czech J. Genet. Plant Breed. 42S:42-44.

16. Goates, B. J., and Peterson, G. L. 1999. Relationship between soilborne and seedborne inoculum density and the incidence of dwarf bunt of wheat. Plant Dis. 83:819-824.

17. Hao, J. J., and Subbarao, K. V. 2005. Comparative analyses of lettuce drop epidemics caused by Sclerotinia minor and S. sclerotiorum. Plant Dis. 89:717-725.

18. Holmes, G. J., Jackson, L. F., and Perring, T. M. 1997. Imperial Valley conditions limit Karnal bunt in wheat. Calif. Agric. 51:29-33.

19. Husman, S., and Ottman, M. 2004. Irrigation of small grains in Arizona. University of Arizona, Coop. Ext. Bull. AZ1345.

20. Inman, A., Magnus, H. A., Riccioni, L., Hughes, K., Coates, M., Barnes, A., Barton, V., Sansford, C., Valvassori, M., Di Giambattista, G., Porta-Puglia, A., Razzaghian, J., and Peterson, G. 2008. Survival of Tilletia indica teliospores under European soil conditions. Plant Pathol. 57:290-300.

21. Jhorar, O. P., Mavi, H. S., Sharma, I., Mahi, G. S., Mathauda, S. S., and Singh, G. 1992. A biometeorological model for forecasting Karnal bunt disease of wheat. Plant Dis. Res. 7:204-209.

22. Jones, D. R. 1987. Seedborne diseases and the international transfer of plant genetic resources: An Australian perspective. Seed Sci. Technol. 15:765-776.

23. Jones, D. R. 2007. Arguments for a low risk of establishment of Karnal bunt disease of wheat in Europe. Eur. J. Plant Pathol. 118:93-104.

24. Jones, D. R. 2007. A reappraisal of the current status of Tilletia indica as an important quarantine pest for Europe. Eur. J. Plant Pathol. 118:105-113.

25. Jones, D. R. 2009. Towards a more reasoned assessment of the threat to wheat crops from Tilletia indica, the cause of Karnal bunt disease. Eur. J. Plant Pathol. 123:247-259.

26. Joshi, L. M., Singh, D. V., and Srivastava, K. D. 1983. Karnal bunt: A minor disease that is now a threat to wheat. Bot. Rev. 49:309-330.

27. Khan, A., Atibalentja, N., and Eastburn, D. M. 2000. Influence of inoculum density of Verticillium dahliae on root discoloration of horseradish. Plant Dis. 84:309-315.

28. Miller, T. C., and Webster, R. K. 2001. Soil sampling techniques for determining the effect of cultural practices on Rhizoctonia oryzaesativae inoculum in rice field soils. Plant Dis. 85:967-972.

29. Murray, G. M., and Brennan, J. P. 1998. The risk to Australia from Tilletia indica, the cause of Karnal bunt of wheat. Aust. Plant Pathol. 27:212-225.

30. Murray, G. M., and Sansford, C. E. 2005. How Tilletia indica overcomes the allee effect. Page 256 in: 15th Bienn. Australas. Plant Pathol. Soc. Conf. Handb. Deakin University Waterfront Campus, Geelong, Victoria, Australia.

31. Ottman, M. 2004. Small grain growth and development. University of Arizona, Coop. Ext. Bull. AZ1347.

32. Pospisil, A., Benada, J., Nedomova, L., and Polisenska, I. 2000. Incidence variability of wheat bunts (Tilletia caries (DC) Tul. and T. laevis Kühn) in field trials. Z. Pflanzenk Pflanzen. 107:74-80.

33. Riccioni, L., Inman, A., Magnus, H. A., Valvassori, M., Porta-Puglia, A., Conca, G., Di Giambattista, G., Hughes, K., Coates, M., Bowyer, R., Barnes, A., Sansford, C. E., Razzaghian, J., Prince, A., and Peterson, G. L. 2008. Susceptibility of European bread and durum wheat cultivars to Tilletia indica. Plant Pathol. 57:612-622.

34. Rush, C. M., Stein, J. M., Bowden, R. L., Riemenschneider, R., Boratynski, T., and Royer, M. H. 2005. Status of Karnal bunt of wheat in the United States 1996 to 2004. Plant Dis. 89:212-223.

35. Sansford, C. E. 1996. Karnal bunt (Tilletia indica): Provisional Pest Risk Analysis: An assessment of the current situation in the USA and the potential risk to the European Community. Central Science Laboratory internal document, York, UK.

36. Sansford, C. 1998. Karnal bunt (Tilletia indica): Detection of Tilletia indica in the US: Potential risk to the UK and the EU. Pages 273-302 in: Proc. Bunts and Smuts of Wheat: An International Symposium, Raleigh, NC, USA.

37. Sansford, C. 2004. UK pest risk analysis for Tilletia indica. Central Science Laboratory for Plant Health Division, Department for Environment, Food and Rural Affairs, UK.

38. Sansford, C., Baker, R., Brennan, J., Ewert, F., Gioli, B., Inman, A., Kelly, P., Kinsella, A., Leth, V., Magnus, H., Miglietta, F., Murray, G., Peterson, G., Porta-Puglia, A., Porter, J., Rafoss, T., Riccioni, L., Thorne, F., and Valvassori, M. 2006. Risks associated with Tilletia indica, the newly-listed EU quarantine pathogen, the cause of Karnal bunt of wheat. EC 
Fifth Framework Project QLK-19990-01554: Risks Associated with Tilletia indica, the newly Listed E.U. Quarantine Pathogen, the Cause of Karnal Bunt of Wheat.

39. Sansford, C. E., Baker, R. H. A., Brennan, J. P., Ewert, F., Gioli, B., Inman, A., Kinsella, A., Magnus, H. A., Miglietta, F., Murray, G. M., Porta-Puglia, A., Porter, J. R., Rafoss, T., Riccioni, L., and Thorne, F. 2008. The new Pest Risk Analysis for Tilletia indica, the cause of Karnal bunt of wheat, continues to support the quarantine status of the pathogen in Europe. Plant Pathol. 57:603-611.

40. Sharma, R. C., Sharma, I., Garrett, K. A., and Bowden, R. L. 2008. Seed borne inoculum and Karnal bunt infection risks in wheat. Bienn. Workshop Smut Fungi. Beltsville, MD, USA.

41. Smilanick, J. L., Dupler, M., Goates, B. J., Hoffman, J. A., Clark, D., and Dobson, D. 1986. Germination of teliospores of Karnal, dwarf, and common bunt fungi after ingestion by animals. Plant Dis. 70:242-244.

42. Smiley, R. W. 1997. Risk assessment for Kar- nal bunt occurrence in the Pacific Northwest. Plant Dis. 81:689-692.

43. Spotts, R. A., and Cervantes, L. A. 2001. Disease incidence-inoculum dose relationship for Botrytis cinerea and Penicillium expansum and decay of pear fruit using dry, airborne conidia. Plant Dis. 85:755-759.

44. Stansbury, C. D., and McKirdy, S. J. 2002. Forecasting climate suitability for Karnal bunt of wheat: A comparison of two meteorological methods. Aust. Plant Pathol. 31:81-92.

45. Stansbury, C. D., and Pretorius, Z. A. 2001. Modelling the potential distribution of Karnal bunt of wheat in South Africa. S. Afr. J. Plant Soil 18:159-168.

46. Stein, J. M., Maples, H. W., and Rush, C. M. 2005. Epidemiology of Tilletia indica teliospores in regulated wheat fields in Texas. Plant Dis. 89:828-833.

47. Waldow, F., and Jahn, M. 2007. Investigations in the regulation of common bunt (Tilletia tritici) of winter wheat with regard to threshold values, cultivar susceptibility and non- chemical protection measures. J. Plant Dis. Prot. 114:269-275.

48. Warham, E. J. 1986. Karnal bunt disease of wheat: A literature review. Trop. Pest Manage. 32:229-242.

49. Wiese, M. V. 1987. Compendium of Wheat Diseases, 2nd ed. American Phytopathological Society, St. Paul, MN

50. Workneh, F., Allen, T. W., Nash, G. H., Narasimhan, B., Srinivasan, R., and Rush, C. M 2008. Rainfall and temperature distinguish between Karnal bunt positive and negative years in wheat fields in Texas. Phytopathology 98:95-100.

51. Xiao, C. L., and Subbarao, K. V. 1998. Relationships between Verticillium dahliae inoculum density and wilt incidence, severity, and growth of cauliflower. Phytopathology $88: 1108-1115$.

52. Ykema, R. E., Floyd, J. P., Palm, M. E., and Peterson, G. L. 1996. First report of Karnal bunt of wheat in the United States. Plant Dis 80:1207. 